\title{
Time of incorporation of field legume herbage and its influence on the growth and yield of upland rice
}

\author{
Berta C. Ratilla' and Rodolfo G. Escalada² \\ 'Department of Agronomy and Soil Science and \\ Department of Genetic Resources and Plant Breeding, Leyte State University, \\ Baybay. Leyte, Philippines
}

\section{ABSTRACT}

Ratilla, B. C. and R. G. Escalada. 2006. Time of incorporation of field legume herbage and its influence on the growth and yield of upland rice. Ann. Trop. Res. 28(2):12-31.

Three species of legumes such as mungbean, cowpea, amd bushbean were incorporated into the soil at flowering to later stages of growth namely; after 1st, 2nd, and 3 rd priming operations. These were followed by two croppings of upland rice.

Significantly lower soil bulk densities were obtained after the first crop of rice when mungbean and bushbean herbage were used as green manure. The pH, O.M. , P and $\mathrm{K}$ contents of the soil planted to rice were not markedly affected by the species and timing of field legume incorporation. Interaction effects between the two variables on $O$. $\mathrm{M}$. and $\mathrm{pH}$ were noted after the harvest of the first and second crops of rice, respectively.

Most of the growth and yield parameters of both crops of rice were not significantly influenced by the treatments involved. This indicates the feasibility of modifying the usual practice of green manuring at flowering stage to later stages of growth using grain legumes without necessarily sacrificing their expected yields. Cowpea was the most suitable green manure crops for upland rice. Its use resulted in the highest combined net income for two croppings of rice, generating $\mathrm{PhP} 48,698.98 \mathrm{ha}^{-1}$ or $\mathrm{PhP} 2.12$ income per peso invested.

Regardless of field legumes used, herbage incorporation after the first priming generated an income of PhP1.56 per peso invested while green manuring at flowering stage gave only PhP0.69.

Keywords: green manuring, time of incorporation, field legume herbage, upland rice

Correspondence: B. C. Ratilla Present Address: Department of Agronomy and Soil Science, Leyte State University, Baybay, Leyte, Philippines 6521-A Tel. No.(053) 335-2627 


\section{INTRODUCTION}

Upland rice is widely grown throughout the Philippines, especially in Southem Luzon and Mindanao. Unlike lowland rice, this crop primarily depends on rainfall for its moisture requirement. A lot of problems confront farmers in growing this crop for optimum yield. One of these is the poor fertility status of the soil. Compared to lowland soils, upland rice soils are generaly deficient in nutrients, especially nitrogen and phosphorus.

The common practice of farmers is to apply inorganic fertilizer into the soil to augment poor fertility. However, due to high cost of inorganic fertilizers, farmers are discouraged from applying them as recommended, or if ever they do, only at minimal amount producing low grain yield (Javier 2002). Continuous application of inorganic fertilizers, on the other hand, poses ill effects not only to the environment but human beings as well. It is, therefore, imperative to look for alternative ways of improving the present practice for increased and sustainable crop production.

Green manuring, a practice of incorporating green plant materials into the soil to improve its properties, has been found as an altemative or supplement to costly inorganic fertilizers. These materials may bring about a number of favorable effects in maintaining or raising soil productivity. Sullivan (2003a) reported that green manures not only add organic matter and $\mathrm{N}$ into the soil but also help conserve water and nutrients. They improve aggregation, thus, improving soil structure and tilth. Thompson and Troeh (1973) claimed that organic residues also increase microbial population and its activity in the soil thereby, enhancing release of nutrient elements.

Legumes are plant species most often used as green manure crops because of their $\mathrm{N}$-fixing abilities and when their herbage are timely incorporated into the soil, help provide stability of soil structure for optimum plant growth (Capuno et al., 1980). Wesscott et al. (1988), as cited by Sullivan (2003b), reported that leguminous green manure crops can supply $30-50 \%$ of the nitrogen needs of high yielding rice varieties. He further added that the availability of green-manure nitrogen depends on the quantity, quality, and type of green manure crop, the time and method of application, soil fertility and cropping method. Ogbonna and Mabbayad (1984), however, claimed that despite these benefits, the added gain from green manuring is not sufficient to justify the loss incurred by tying up the land for the time required to produce 
the green manure crop.

At present, many small farmers are still reluctant to adopt the said technology realizing the futility of just plowing under the legume crop at flowering stage. Most often, they do not appreciate planting a crop without obtaining direct economic advantage. Hence, it is important to determine the appropriate and suitable time of incorporating green manures from flowering stage to later part of crop growth, to encourage farmers to accept and adopt the technology.

This paper presents the effects of three field legumes as green manure crops on upland rice production. Specifically, this focuses on evaluating the effects of time of incoporation of field legume herbage as green manure on some soil properties and on the succeeding crops of upland rice to find out the most suitable time of incorporating green manure for upland rice, and determine the profitability of incorporating field legumes into the soil as green manure at their varying stages of growth.

\section{MATERIALS AND METHODS}

The experiment was conducted at the experimental field of the Leyte State University, Baybay, Leyte, Philippines. The soil was clay loam having a

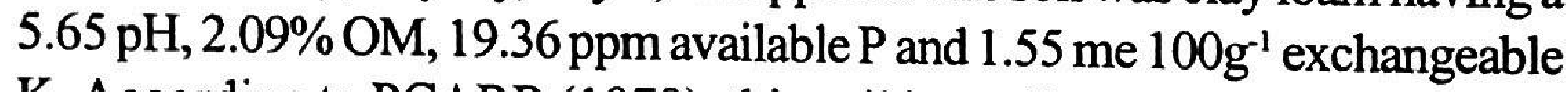
$\mathrm{K}$. According to PCARR (1978), this soil is medium acidic with medium content of organic matter and with adequate to very high contents of $\mathrm{P}$ and $\mathrm{K}$, respectively. The area had a total annual rainfall of $2060 \mathrm{~mm}$ and average daily temperatures of $24.64^{\circ} \mathrm{C}$ (minimum) and $31.3^{\circ} \mathrm{C}$ (maximum).

An experimental area of $1,107 \mathrm{~m}^{2}$ was laid out in a split plot arranged in $\mathrm{RCBD}$ with 3 replications. The experiment included three species of field legumes as main plot: $\mathrm{L}_{1}=$ mungbean, $\mathrm{L}_{2}=$ cowpea, $\mathrm{L}_{3}=$ bushbean, with the time of incorporation of the herbage into the soil as subplot: $\mathrm{T}_{1}=$ at flowering stage, $\mathrm{T}_{2}, \mathrm{~T}_{3}$ and $\mathrm{T}_{4}=$ after 1st, 2 nd and 3rd priming, respectively. The unit plot had an area of $20 \mathrm{~m}^{2}$.

Planting of the green manure crops was synchronized accordingly such that their incorporation was done at the same time. It was done by drilling the seeds in furrows at the rate of 18,25 and $30 \mathrm{~kg} \mathrm{ha}^{-1}$ for mungbean, bushbean, and cowpea, respectively. They were thinned to 15 plants per linear meter to attain a uniform plant population of 300,000 per hectare. 
Incorporation of herbage of field legumes as specified in the treatments was done by plowing under the chopped herbage using a carabao-drawn implement one month prior to planting upland rice. Seeds of upland rice (UPL $\mathrm{Ri}-7)$ were drilled in furrows at the rate of $80 \mathrm{~kg} \mathrm{ha}^{-1}$. Two croppings of upland rice followed after the incorporation of field legume herbage. Only the first crop was applied with $30-20-0 \mathrm{~kg} \mathrm{ha}^{-1} \mathrm{~N}, \mathrm{P}_{2} \mathrm{O}_{5}, \mathrm{~K}_{2} \mathrm{O}$. This rate of fertilizer application was partially based on the results of the initial soil analysis and the recommendation rate of upland rice which was $40 \mathrm{~kg} \mathrm{~N}, 20 \mathrm{~kg} \mathrm{P}_{2} \mathrm{O}_{s}$, and none of $\mathrm{K}_{2} \mathrm{O}$ (PCARR 1978). With $30 \mathrm{~kg} \mathrm{~N} \mathrm{ha}^{-1}$, the remaining $10 \mathrm{~kg}$ had been assumed to be supplied by the green manure crops. The second rice crop obtained its nutrients from the previously incorporated green manure and inorganic fertilizers applied.

Both green manure and test crops were weeded three times after planting. Irrigation was applied when soil moisture was limited. Priming of grain legumes was done at one week interval based on the frequency of priming specified in the treatment. Upland rice was harvested by cutting the stalks with a sickle and then threshed. Grains were cleaned and dried to $14 \% \mathrm{MC}$.

Bulk density values of the soil planted to upland rice were determined using the core method. Separate soil samples from each treatment plot were collected at $0-15 \mathrm{~cm}$ depth and were analyzed for soil $\mathrm{pH}, \mathrm{OM}(\%)$, available $\mathrm{P}$ (ppm) and exchangeable $\mathrm{K}$ (me $100 \mathrm{~g}^{-1}$ ) contents on the following periods:

a) before incorporation of green manure crop

b) one month after incorporation of green manure crop

c) after each harvest of upland rice for 2 croppings

Plant samples of rice were also gathered at panicle initiation for the determination of percent total N, P, and K contents.

\section{RESULTS AND DISCUSSION}

\section{Effects of green manuring on soil bulk density}

Among the three field legumes used as green manure crops, bulk density values of soil taken before and after their incorporation did not vary significantly (Table 1). It was only after the first rice crop that lower values were obtained 
Table I. Bulk density and $\mathrm{pH}$ of the soil planted to upland rice as influenced by herbage of field legumes and times of their incorporation

Treatments

\begin{tabular}{llllllll}
\multicolumn{4}{l}{ Bulk Density $\left(\mathrm{g} \mathrm{cm}^{-3}\right)$} & & \multicolumn{3}{c}{ Soil pH } \\
\hline Before & One & After & After & Before & One & After & After \\
appli- & month & the 1st & the 2nd & appli- & month & the 1st & the 2nd \\
cation & after & rice & rice & cation & after & rice & rice \\
of & green & crop & crop & of & green & crop & crop \\
green & manu- & & & green & manu- & & \\
manure & ring & & & manure & ring & & \\
\hline
\end{tabular}

Field legumes

$\begin{array}{lllllllll}\text { Mungbean } & 1.24 & 1.12 & 1.21 \mathrm{~b} & 1.24 & 6.27 & 6.28 & 6.17 & 6.53 \\ \text { Cowpea } & 1.26 & 1.14 & 1.24 \mathrm{a} & 1.24 & 6.26 & 6.24 & 6.22 & 6.50 \\ \text { Bushbean } & 1.22 & 1.10 & 1.20 \mathrm{~b} & 1.26 & 6.27 & 6.26 & 6.28 & 6.65\end{array}$

Time of Incorporation

\begin{tabular}{|c|c|c|c|c|c|c|c|c|}
\hline At flowering & $1.19 \mathrm{~b}$ & 1.12 & 1.22 & 1.24 & 6.26 & 6.25 & 6.25 & 6.57 \\
\hline $\begin{array}{l}\text { After 1st priming } \\
\text { After } 2 \text { nd }\end{array}$ & $1.24 \mathrm{a}$ & 1.14 & 1.22 & 1.23 & 6.30 & 6.24 & 6.23 & 6.56 \\
\hline $\begin{array}{l}\text { priming } \\
\text { After 3rd }\end{array}$ & $1.27 \mathrm{a}$ & 1.11 & 1.20 & 1.28 & 6.27 & 6.27 & 6.21 & 6.54 \\
\hline priming & $1.27 \mathrm{a}$ & 1.13 & 1.22 & 1.24 & 6.24 & 6.29 & 6.20 & 6.57 \\
\hline C.V.(a) & 3.18 & 3.09 & 1.61 & 5.65 & 2.53 & 1.60 & 4.82 & 3.05 \\
\hline C.V.(b) & 3.63 & 4.71 & 5.36 & 3.79 & 1.89 & 1.96 & 2.27 & 1.52 \\
\hline
\end{tabular}

Treatment means within each column designated by a common letter and those without letter are not significantly different at 5\% level, DMRT.

in mungbean and bushbean manured plots. The appreciable amount of biomass incorporated from the latter promoted soil aggregation. But surprisingly, in mungbean plot, despite the lower herbage produced, lower bulk density values were recorded. Probably, some factors might have affected this parameter and this needs further investigation. The result also indicated a noticeable decrease in bulk density values one month after incorporation of green manure than before green manures were incorporated.

Higher bulk density values were obtained among plots where harvesting of pods was performed before its incorporation. Turning under the soil of the green manure crop at flowering stage resulted in the lowest bulk density values 
Table 2.Organic matter (\%) and phosphorus ( $\mathrm{ppm}$ ) of the soil planted to upland rice as influenced by herbage of field legumes and times of their incorporation

Treatments

\begin{tabular}{|c|c|c|c|c|c|c|c|}
\hline & \multicolumn{4}{|c|}{ Organic Matter (\%) } & \multicolumn{3}{|c|}{ Phosphorus (ppm) } \\
\hline $\begin{array}{l}\text { Before } \\
\text { appli- } \\
\text { cation } \\
\text { of } \\
\text { green } \\
\text { manure }\end{array}$ & $\begin{array}{l}\text { One } \\
\text { month } \\
\text { after } \\
\text { green } \\
\text { manu- } \\
\text { ring }\end{array}$ & $\begin{array}{l}\text { After } \\
\text { the Ist } \\
\text { rice } \\
\text { crop }\end{array}$ & $\begin{array}{l}\text { After } \\
\text { the } 2 \text { nd } \\
\text { rice } \\
\text { crop }\end{array}$ & $\begin{array}{l}\text { Before } \\
\text { appli- } \\
\text { cation } \\
\text { of } \\
\text { green } \\
\text { manure }\end{array}$ & $\begin{array}{l}\text { One } \\
\text { month } \\
\text { after } \\
\text { green } \\
\text { manu- } \\
\text { ring }\end{array}$ & $\begin{array}{l}\text { After } \\
\text { the } 1 \text { st } \\
\text { rice } \\
\text { crop }\end{array}$ & $\begin{array}{l}\text { After } \\
\text { the } 2 \text { nd } \\
\text { rice } \\
\text { crop }\end{array}$ \\
\hline
\end{tabular}

Field legumes

Mungbean

$\begin{array}{llllllll}2.79 & 1.96 & 2.86 & 2.72 & 13.28 & 16.58 & 13.52 & 6.26 \\ 2.52 & 2.18 & 3.04 & 2.94 & 13.31 & 16.50 & 12.93 & 15.34 \\ 2.56 & 1.76 & 3.10 & 3.38 & 13.60 & 17.50 & 13.95 & 15.80\end{array}$

Bushbean

Time of Incorporation

\begin{tabular}{|c|c|c|c|c|c|c|c|c|}
\hline At flowering & 2.80 & 1.81 & 2.90 & 3.10 & 14.07 & 16.40 & 13.42 & 15.72 \\
\hline After 1st priming & 2.76 & 2.15 & 3.02 & 2.83 & 13.33 & 17.53 & 1328 & 15.93 \\
\hline $\begin{array}{l}\text { After } 2 \text { nd } \\
\text { priming } \\
\text { After } 3 \text { rd }\end{array}$ & 2.42 & 2.04 & 2.92 & 3.42 & 13.02 & 16.44 & 13.30 & 15.04 \\
\hline priming & 2.50 & 1.87 & 3.16 & 2.70 & 13.17 & 17.07 & 13.87 & 16.51 \\
\hline C.V.(a) & 40.89 & 30.61 & 27.90 & 26.16 & 5.23 & 6.76 & 8.13 & 5.72 \\
\hline C.V.(b) & 28.31 & 19.09 & 8.82 & 32.21 & 12.99 & 11.68 & 10.02 & 11.41 \\
\hline
\end{tabular}

Treatment means within each column designated by a common letter and those without letter are not significantly different at $5 \%$ level, DMRT.

$\left(1.19 \mathrm{~g} \mathrm{~cm}^{-1}\right)$. Priming or harvesting operation in this case enhanced compaction of soil surface thus, increasing the bulk density values. This confirmed what Brady (1984) mentioned that the soil and system of crop management employed would likely influence the bulk density of surface layers of the soil.

On the other hand, bulk density values declined one month after green manure incorporation, indicating an improved granulation due to the added residues from the legumes hence, lowering the weight of surface soils. 
Table 3. Exchangeable potassium content of the soil planted to upland rice as influenced by herbage of field legumes and times of their incorporation

Treatments

Exchangeable Potassium Content (meq/100g)

\begin{tabular}{|c|c|c|c|}
\hline $\begin{array}{l}\text { Before application } \\
\text { of green manure }\end{array}$ & $\begin{array}{l}\text { One month } \\
\text { after green } \\
\text { manuring }\end{array}$ & $\begin{array}{l}\text { After the } \\
\text { 1st rice } \\
\text { crop }\end{array}$ & $\begin{array}{l}\text { After the } \\
\text { 2nd rice } \\
\text { crop }\end{array}$ \\
\hline
\end{tabular}

Field legumes

$\begin{array}{lllll}\text { Mungbean } & 0.72 & 1.01 & 0.92 & 1.31 \\ \text { Cowpea } & 1.26 & 0.64 & 0.98 & 0.78 \\ \text { Bushbean } & 0.69 & 1.08 & 0.90 & 1.32\end{array}$

Time of Incorporation

\begin{tabular}{|c|c|c|c|c|}
\hline At flowering & 0.67 & 1.01 & 0.84 & 1.30 \\
\hline After 1st priming & 0.69 & 1.05 & 0.85 & 1.29 \\
\hline After 2nd priming & 0.68 & 1.00 & 0.86 & 1.27 \\
\hline After 3rd priming & 0.70 & 1.01 & 0.89 & 1.32 \\
\hline C. V. (a) & 16.1 & 7.75 & 16.48 & 18.48 \\
\hline C. V. (b) & 14.54 & 16.98 & 6.67 & 17.24 \\
\hline
\end{tabular}

Treatment means within each column designated by a common letter and those without letter are not significantly different at $5 \%$ level, DMRT

Effects of green manuring on soil $\mathrm{pH}$, percent organic matter, available $P$ and exchangeable $K$ contents

Using mungbean, bushbean and cowpea as green manure and the stages of their soil incorporation did not significantly affect the aforementioned soil parameters (Tables 1-3).This means that the herbage of any of these legumes can be incorporated anytime even after a number of harvesting or priming operations without drastic changes in soil pH to both extremes (acidity and alkalinity). However, marked interactions were noted on soil $\mathrm{pH}$ after harvesting of the second rice crop and soil OM after the first succeeding rice crop (Figure 1). Interaction effects observed after the harvest of the first rice crop showed that incorporation of bushbean after the first priming resulted in significantly 
Table 4 . The $N, P, K$ contents of upland rice at panicle initiation stage as influenced by herbage of field legume and time of their incorporation

\begin{tabular}{|c|c|c|c|c|c|c|}
\hline \multirow[t]{3}{*}{ Treatments } & \multirow{2}{*}{\multicolumn{2}{|c|}{ Nitrogen }} & \multicolumn{4}{|c|}{ Total Analysis (\%) } \\
\hline & & & \multicolumn{2}{|c|}{ Phosphorus } & \multicolumn{2}{|c|}{ Potassium } \\
\hline & Ist crop & 2nd crop & 1st crop & 2nd crop & 1st crop & 2nd crop \\
\hline \multicolumn{7}{|l|}{ Field legumes } \\
\hline Mungbean & 2.02 & 1.48 & 0.16 & 0.27 & 1.91 & 1.56 \\
\hline Cowpea & 1.95 & 1.66 & 0.17 & 0.26 & 1.95 & 1.62 \\
\hline Bushbean & 1.87 & 1.46 & 0.17 & 0.27 & 2.04 & 1.62 \\
\hline \multicolumn{7}{|c|}{ Time of Incorporation } \\
\hline At flowering & 1.93 & 1.51 & 0.16 & 0.26 & 1.89 & $1.55 \mathrm{bc}$ \\
\hline After 1st priming & 2.11 & 1.48 & 0.17 & 0.26 & 1.78 & $1.43 \mathrm{c}$ \\
\hline After 2nd priming & 1.78 & 1.51 & 0.17 & 0.28 & 2.11 & $1.62 \mathrm{~b}$ \\
\hline After 3rd priming & 1.97 & 1.63 & 0.17 & 0.26 & 2.09 & $1.81 \mathrm{a}$ \\
\hline C. V. $(\%) a$ & 26.65 & 16.93 & 9.75 & 24.77 & 1.76 & 10.64 \\
\hline C. V. $(\%) b$ & 21.14 & 13.25 & 8.04 & 7.09 & 1.71 & 10.45 \\
\hline
\end{tabular}

Treatment means within each column designated by a common letter and those without letter designations are not significantly different at $5 \%$ level, DMRT and ANOVA, respectively

higher OM content. A comparably higher OM was likewise noted in bushbean and cowpea manured plots when plowed under after the 3rd priming.

It was observed that after the second rice crop, incorporation of mungbean either at flowering or after the first harvest raised soil $\mathrm{pH}$ to near neutrality similar to cowpea when turned under after 3rd priming. Incorporating mungbean after 3rd priming revealed a lower $\mathrm{pH}$ range comparable when cowpea was incorporated at flowering or after the first and second priming. Bushbean green manure, on the other hand, did not significantly effect soil $\mathrm{pH}$ under different stages of its incorporation.

Effects of green manure on $N, P$, and $K$ contents of rice tissues at panicle initiation stage

Results indicated that the kind of legumes used as green manure did not affect significantly the N, P, and K contents of the first and second crops of 
Table 5. Agronomic characters and grain yield of field legumes prior to incorporation of their herbage

\begin{tabular}{lllll}
\hline Treatments & $\begin{array}{l}\text { Number of } \\
\text { nodules per } \\
\text { plant }\end{array}$ & $\begin{array}{l}\text { Dry weight } \\
\text { of nodules } \\
\text { per plant }\end{array}$ & $\begin{array}{l}\text { Fresh } \\
\text { herbage } \\
\text { yield } \\
\left(\mathrm{t} \mathrm{ha}^{-1}\right)\end{array}$ & $\begin{array}{l}\text { Total Grain } \\
\text { yield }\left(\mathrm{t} \mathrm{ha}^{-1}\right)\end{array}$ \\
\hline
\end{tabular}

Field legumes

$\begin{array}{lrrrr}\text { Mungbean } & 7.20 & 6.13 & 7.69 \mathrm{~b} & 0.44 \mathrm{a} \\ \text { Cowpea } & 3.77 & 8.72 & 10.46 \mathrm{a} & 0.43 \mathrm{a} \\ \text { Bushbean } & 4.93 & 17.19 & 11.26 \mathrm{a} & 0.11 \mathrm{~b}\end{array}$

Time of Incorporation

\begin{tabular}{|c|c|c|c|c|}
\hline At flowering & $15.58 \mathrm{a}$ & $34.18 \mathrm{a}$ & $8.05 \mathrm{c}$ & \\
\hline After 1st priming & $3.11 \mathrm{~b}$ & $3.83 \mathrm{~b}$ & $12.07 \mathrm{a}$ & 0.33 \\
\hline After 2nd priming & $1.23 \mathrm{~b}$ & $3.47 \mathrm{~b}$ & $9.80 \mathrm{~b}$ & 0.30 \\
\hline After 3rd priming & $1.20 \mathrm{~b}$ & $1.24 \mathrm{c}$ & $9.28 \mathrm{bc}$ & 0.35 \\
\hline $\bar{C} \cdot V \cdot(\%) a$ & $\overline{65.53}$ & 71.02 & 13.72 & 37.11 \\
\hline C. V. $(\%) b$ & 78.23 & 40.82 & 16.00 & 22.47 \\
\hline
\end{tabular}

Treatment means within each column designated by a common letter and those without letter designations are not significantly different at $5 \%$ level, DMRT and ANOVA, respectively

rice (Table 4). Generally, results revealed that $\mathrm{N}$ and $\mathrm{K}$ contents of rice were slightly higher during the first cropping of rice but tended to decrease in the 2 nd cropping. This finding suggests the decomposition of the added organic material thus, enhancing the release of these nutrient elements upon mineralization for plant nutrition. Uptake in the 2 nd crop of rice was lesser because no fertilizer was applied into the soil. The 2 nd cropping of rice was expected to have just utilized the residual nutrients left by the preceding crop hence, the lower $\mathrm{N}$ and $\mathrm{K}$ concentrations in ther tissues.

In the case of total $\mathrm{P}(\%)$, the 1 st crop of rice had relatively lower contents than the subsequent crop. It can be inferred that microorganisms responsible for the decay process had utilized some of this nutrient element for their cell synthesis (Brady, 1984). As such, its availability as reflected by the extent of 


\section{P nutrient uptake by the plants was reduced.}

Only potassium on the 2 nd crop of rice was affected by the time of herbage incorporation into the soil. Significantly higher $\mathrm{K}(1.81 \%)$ was noted when field legumes were plowed under after the $3 \mathrm{rd}$ priming followed by those incorporated after the 2 nd priming (1.62\%), and at flowering stage $(1.55 \%)$. Plants in plots where herbage were incorporated after the 1st priming had the least $K$ contents $(1.43 \%)$ and was comparable to those where herbage was turned under at flowering stage. This finding simply suggests that the turning of green manures at later stages of growth still ensures greater availability of $\mathrm{K}$ nutrient in the soil for use by the succeeding crop.

\section{Performance of field legumes as green manure crop}

The amount of fresh herbage and grain yields significantly differ among the kind of legumes used (Table 5). Considerably lower fresh herbage was obtained from mungbean $\left(7.69 \mathrm{t} \mathrm{ha}^{-1}\right)$ compared to cowpea $\left(10.46 \mathrm{t} \mathrm{ha}^{-1}\right)$ and bush bean $\left(11.26 \mathrm{tha}^{-1}\right)$. Their marked differences could be related to their inherent species characteristics. In terms of total grain yield, bushbean produced the lowest at $0.11 \mathrm{tha}^{-1}$, while mungbean and cowpea had higher grain yields of 0.44 and $0.43 \mathrm{tha}^{-1}$, respectively. A mosaic virus infection on bushbean greatly affected its pod and grain formation.

The number and dry weight of nodules did not differ considerably among legumes. However, their stages of growth before turning under the soil influenced the number and dry weight of nodules as well as the quantity of biomass produced.

Results showed that nodule count and its dry weight were higher at flowering stage. As the legumes matured, the number and consequent dry weight decreased since some of them had deteriorated or had sloughed off from the roots. In terms of biomass that was plowed under, it was after the first priming that the highest biomass (12.07 tha-1) was produced as it includes young and immature pods. Those in the 2 nd and 3 rd primings were more of foliage only since pods at this stage were physiologically mature and harvestable. The amount of biomass at flowering stage was the lowest $\left(8.05 \mathrm{t} \mathrm{ha}^{-1}\right)$ which was comparable to those obtained after 3 priming operations.

Mungbean and cowpea obtained heavier grain yield than bushbean prior 

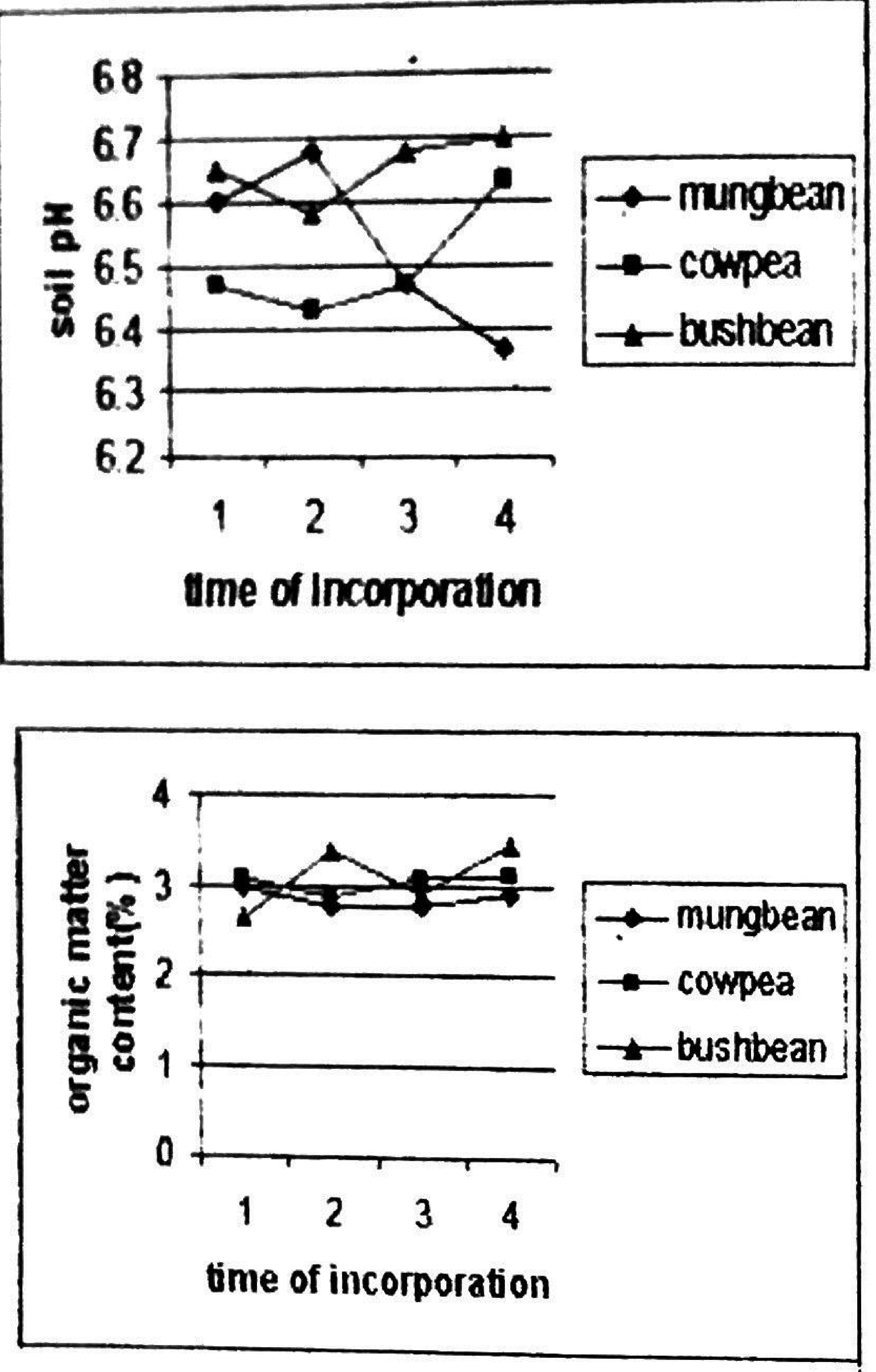

Note:

$\begin{array}{ll}1 \text { - at flowering } & \text { 2-after 1st priming } \\ 2 \text {-after 2nd priming } & 3 \text {-after 3rd priming }\end{array}$

Figure 1. Interaction effects of field legumes and their time of incorporation on the $\mathrm{pH}$ and organic matter content of the soil after the 2 nd and 1st rice crops, respectively. 


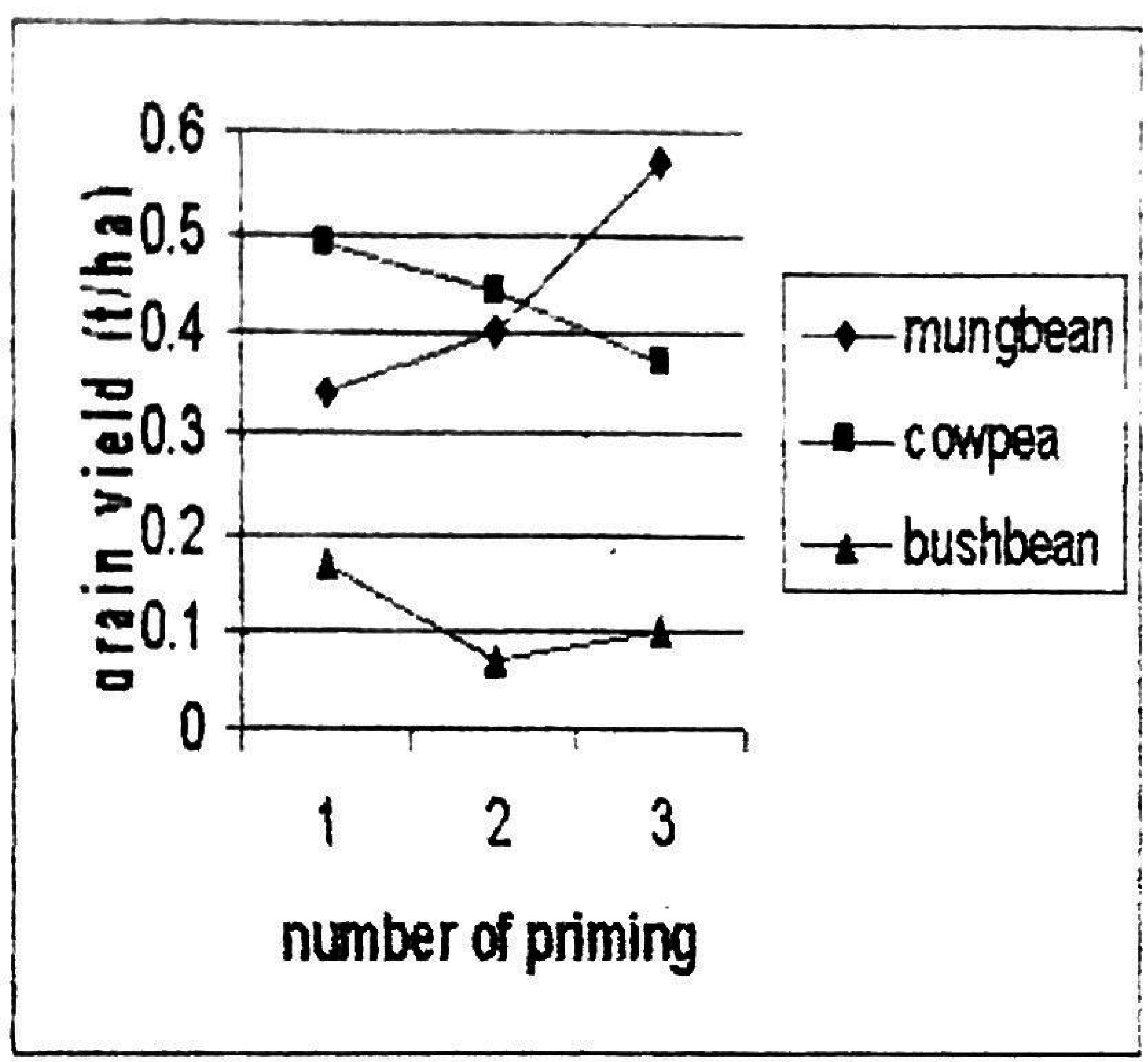

Figure 2. Interaction effects of field legumes and number of priming on their total grain yield

to their herbage incorporation into the soil (Fig. 2). Similarly, mungbean that was primed 3 times gave appreciably higher yield than those primed once or twice. With cowpea, one or two primings yielded more than those primed 3 times which means that the yield obtained at the 3rd priming was negligible. The low yield obtained from bushbean was primarily due to disease infection caused by viral mosaic. The infection resulted in the curling of leaves and stunting of plants, thus affecting their reproductive processes. Nevertheless, regardless of field legumes, total grain yield was relatively higher with 3 times priming.

Effects of green manuring on the agronomic characters of upland rice

In the first cropping, upland rice considerably produced higher straw yield in bushbean-manured plots than with mungbean and cowpea (Table 6). 
Table 6 . Agronomic characters of upland rice as influenced by field legumes and their time of incorporation (1st cropping)

\begin{tabular}{llll}
\hline Treatments & Leaf Area Index & $\begin{array}{l}\text { Height at } \\
\text { harvest }(\mathrm{cm})\end{array}$ & $\begin{array}{l}\text { Straw } \\
\text { Yield } \\
\left(\mathrm{t} \mathrm{ha} \mathrm{a}^{-1}\right)\end{array}$ \\
\end{tabular}

Ficld legumes

$\begin{array}{llll}\text { Mungbean } & 6.37 & 100.40 & 11.4 \mathrm{~b} \\ \text { Cowpea } & 6.92 & 101.43 & 11.36 \mathrm{~b} \\ \text { Bushbean } & 7.44 & 101.06 & 12.54 \mathrm{a}\end{array}$

Time of Incorporation

\begin{tabular}{|c|c|c|c|}
\hline At flowering & 6.92 & 102.10 & 12.23 \\
\hline After 1st priming & 6.54 & 100.00 & 11.52 \\
\hline After 2 nd priming & 6.95 & 101.43 & 12.24 \\
\hline After 3rd priming & 6.61 & 98.99 & 11.13 \\
\hline C. V. $(\%) \mathrm{a}$ & 27.02 & 3.23 & 6.34 \\
\hline C.V. $(\%) b$ & 19.75 & 3.94 & 12.44 \\
\hline
\end{tabular}

Treatment means within each column designated by a common letter and those without letter designations are not significantly different at 5\% level, DMRT and ANOVA, respectively

However, leaf area index and plant height were statistically similar in different species of grain legumes used. Their various times of herbage incorporation also did not show marked differences on the aforementioned parameters. This means that green manuring using these field legumes can be done not only at flowering stage but at any of the specified times. This further indicated the feasibility of doing the practice at later stages of growth without necessarily losing their expected grain yields. In the 2 nd cropping of rice (Table 7), the same response was noted which further confirmed the results obtained in the 1 st cropping. This also showed the benefits that could be derived from green manuring even if the stage of its incorporation is extended beyond flowering stage. Modifying the usual practice of green manuring at flowering stage to priming stages would mean yield advantage. Instead of just tying up the land in growing the green manure crops, an added economic return could be obtained. 
Table 7. Agronomic characters of upland rice as influenced by field legumes and their time of incorporation ( 2 nd cropping)

\begin{tabular}{|c|c|c|c|}
\hline Treatments & Leaf Area Index & $\begin{array}{l}\text { Height at } \\
\text { harvest }(\mathrm{cm})\end{array}$ & $\begin{array}{l}\text { Straw } \\
\text { Yield } \\
\left(t \mathrm{tha}^{-1}\right)\end{array}$ \\
\hline \multicolumn{4}{|l|}{ Field legumes } \\
\hline Mungbean & 3.51 & 78.93 & 7.30 \\
\hline Cowpea & 3.61 & 77.82 & 8.68 \\
\hline Bushbean & 3.44 & 79.21 & 7.85 \\
\hline \multicolumn{4}{|c|}{ Time of Incorporation } \\
\hline At flowering & 3.34 & 79.90 & 7.66 \\
\hline After 1st priming & 3.16 & 78.85 & 7.80 \\
\hline After 2nd priming & 3.91 & 77.89 & 7.94 \\
\hline After 3rd priming & 3.66 & 77.87 & 8.37 \\
\hline $\bar{c} \cdot \bar{v} \cdot(\%) \mathrm{a}$ & 25.73 & $9 . \overline{25}$ & 17.45 \\
\hline C. V. $(\%) b$ & 21.45 & 6.33 & 17.54 \\
\hline
\end{tabular}

Treatment means within each column designated by a common letter and those without letter designations are not significantly different at $5 \%$ level, DMRT and ANOVA, respectively

Effects of green manuring on yield and yield components and harvest index of upland rice

No marked differences were noted on the yield parameters measured on the 1st and 2nd rice crops (Tables 8 and 9). In the first cropping, an interaction effect was noted on the number of grains/panicle (Fig. 3). Upland rice produced more grains per panicle when cowpea was plowed under after 3 primings. It gave the fewest grains when turned under at flowering stage. The number of grains per panicle in bushbean and mungbean manured rice plants at various times of incorporation were just comparable. This result seemed to suggest that any of the legume tested in this study could be used as green manure and can be incorporated into the soil even beyond flowering, that is, until 3rd priming. 


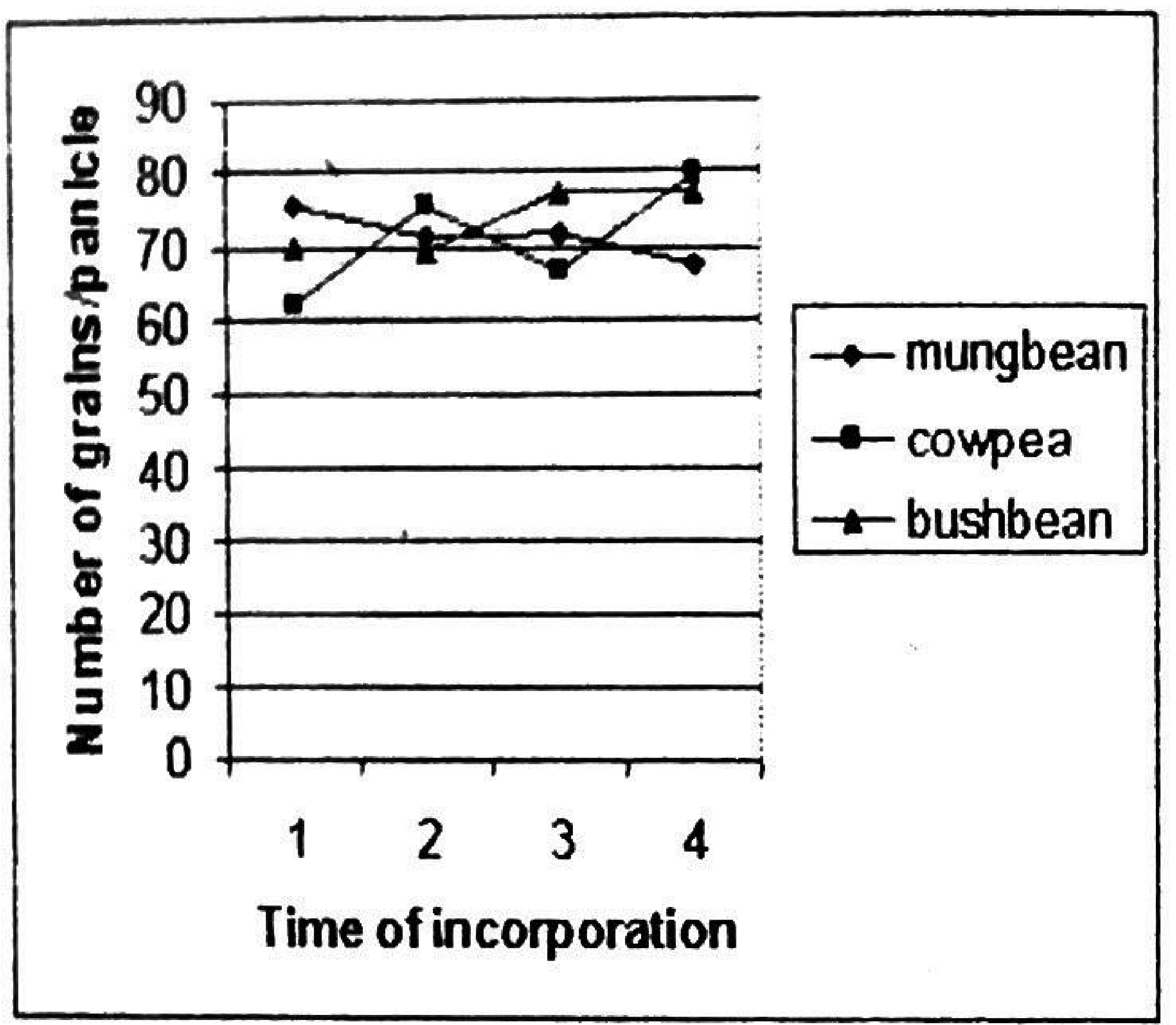

Figure 3. Interaction effects of field legumes and time of their incorporation on the number of grains per panicle of upland rice (1st cropping)

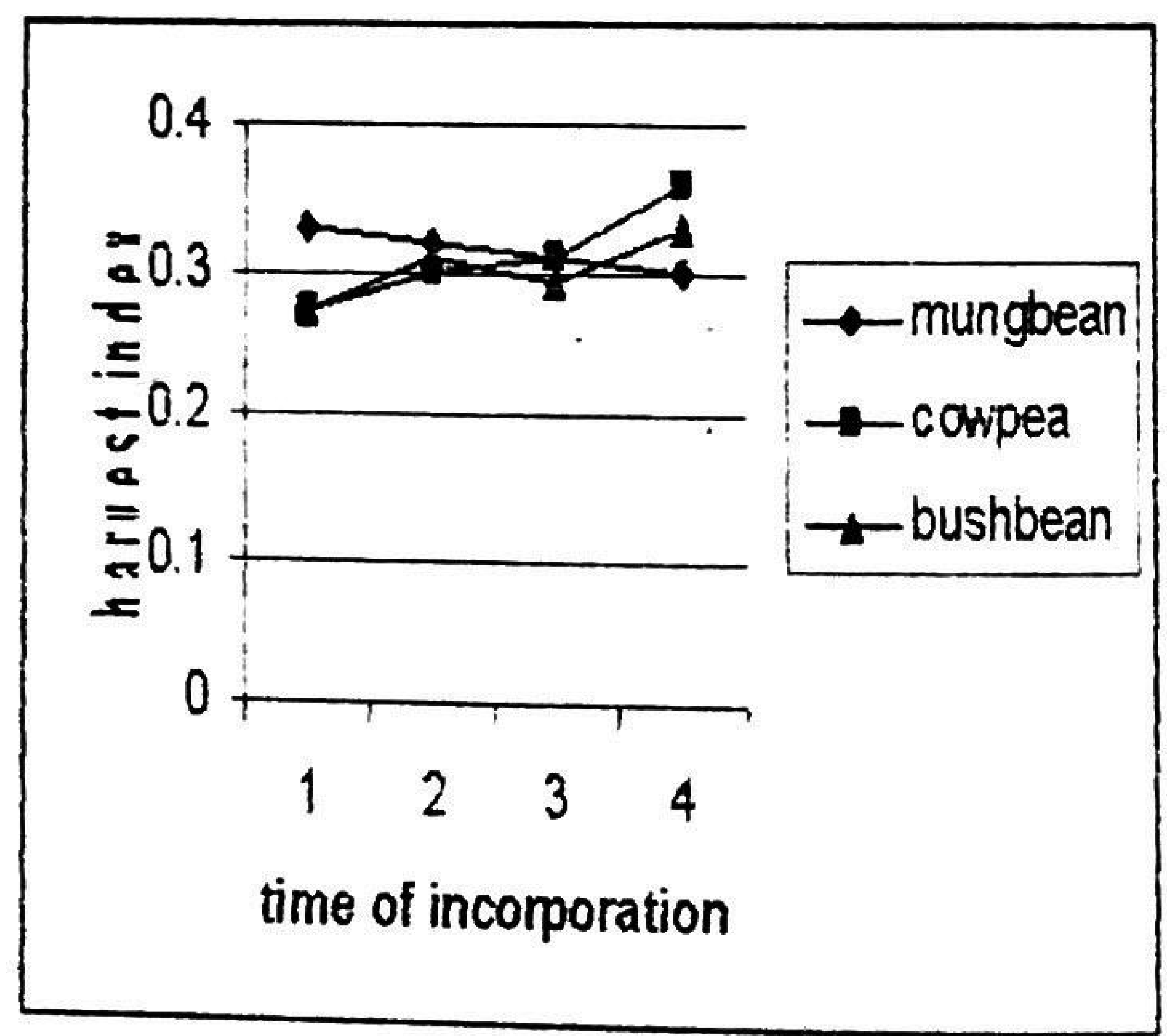

Figure 4. Interaction effects of field legumes and their time of incorporation on harvest index of upland rice ( 1 st crop) 
The highest harvest index values of the first crop of upland rice crop were noted when green manure was turned under the soil after the $3 \mathrm{rd}$ and $1 \mathrm{st}$ primings (Table 8). Lowest $\mathrm{HI}$ was obtained when the green mnaure crop was incorporated into the soil at flowering stage. This result could be related to the greater amount of legume herbage that was incorporated beyond flowering stage which upon decomposition, contributed nutrients to the last rice plant. This consequently increased the ratio of economic yield over the biological yield.

Figure 4 shows that incorporation of mungbean at flowering stage resulted in higher $\mathrm{HI}$ than at $3 \mathrm{rd}$ priming. However, opposite result was obtained when either cowpea or bushbean was used. The high HI obtained when mungbean herbage was incorporated after the 3 rd priming might be attributed to the improvement of soil fertility brought about by the accumulation of organic matter. There was high $\mathrm{OM}$ accumulation when bushbean herbage was turned under after the 3rd priming than it was at flowering stage. On the other hand, the same level of $O M$ increase was noted when mungbean was turned under at flowering stage.

\section{Cost and return}

Table 10 shows that cowpea herbage used as green manure resulted in a higher total net income of PhP48,698.98 ha $\mathrm{a}^{-1}$, followed by mungbean at $\mathrm{PhP} 26,028.98 \mathrm{ha}^{-1}$. Bushbean herbage as green manure gave the least net

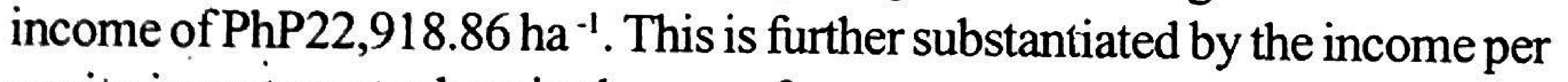
capita investment wherein the use of cowpea as green manure generated PhP2.12 income per peso invested.

Incorporation of green manure at flowering stage produced the lowest income of PhP14,860.14 ha ${ }^{-1}$. It is expected since at this stage, no additional income was generated from the legume. As the green manure crops were allowed to produce grains, additional income was derived. Hence, when the green manure crops were incorporated after priming of pods, higher net income and ROI were attained.

Aside from the known benefits green manuring could provide to the soil, results showed that this practice would be more profitable if the legumes used were allowed to produce grains before their herbage incorporation into the 
Table 8. Yield, yield components and harvest index of upland rice as influenced by field legumes and their time of incorporation (1st cropping)

\begin{tabular}{|c|c|c|c|c|c|c|}
\hline Treatments & $\begin{array}{l}\text { Number } \\
\text { of pani- } \\
\text { cles per } \\
\mathrm{m}^{2}\end{array}$ & $\begin{array}{l}\text { Panicle } \\
\text { length } \\
(\mathrm{cm})\end{array}$ & $\begin{array}{l}\text { Number } \\
\text { of grains } \\
\text { per } \\
\text { panicle }\end{array}$ & $\begin{array}{l}\text { Weight } \\
\text { of grains } \\
\text { per } \\
\text { panicle } \\
\text { (o) }\end{array}$ & $\begin{array}{c}\text { Weight } \\
\text { of } 1000 \\
\text { grains } \\
\text { (g) }\end{array}$ & $\begin{array}{l}\text { Grain Harvest } \\
\text { yield index } \\
\left(\mathrm{t} \mathrm{ha}^{-1}\right)\end{array}$ \\
\hline
\end{tabular}

Field legumes

$\begin{array}{llllllll}\text { Mungbean } & 227.44 & 22.48 & 71.40 & 1.64 & 23.41 & 2.04 & 0.32 \\ \text { Cowpea } & 239.88 & 21.44 & 70.90 & 1.66 & 23.86 & 2.06 & 0.31 \\ \text { Bushbean } & 228.88 & 22.57 & 73.46 & 1.73 & 24.06 & 2.11 & 0.30\end{array}$

Time of Incorporation

\begin{tabular}{|c|c|c|c|c|c|c|c|}
\hline \multirow{4}{*}{$\begin{array}{l}\text { At flowering } \\
\text { After 1st } \\
\text { priming } \\
\text { After 2nd } \\
\text { priming } \\
\text { After 3rd } \\
\text { priming }\end{array}$} & 235.42 & 21.89 & 69.09 & 1.60 & 23.67 & 2.02 & $0.29 c$ \\
\hline & 227.70 & 22.22 & 71.94 & 1.65 & 23.39 & 2.13 & $0.31 \mathrm{ab}$ \\
\hline & 238.52 & 22.06 & 71.87 & 1.70 & 24.13 & 2.11 & $0.30 \mathrm{bc}$ \\
\hline & 226.66 & 22.49 & 74.80 & 1.75 & 23.91 & 2.04 & $0.33 \mathrm{a}$ \\
\hline & 7.21 & 5.8 & 12.25 & 13.12 & 3.6 & 7.64 & 18.19 \\
\hline C. V. $(\%) b$ & 7.55 & 3.06 & 8.69 & 12.34 & 4.59 & 11.05 & 5.30 \\
\hline
\end{tabular}

Treatment means within each column designated by a common letter and those without letter designations are not significantly different at $5 \%$ level, DMRT and ANOVA, respectively

soil. The amount of herbage that can be incorporated at this stage is heavier as it includes the immature pods. Likewise, at this stage, pod/seed formation is at its peak.

\section{CONCLUSION AND IMPLICATION}

Generally, the time of incorporation of field legume herbage did not 
Table 9. Yield, yield components and harvest index of upland rice as influenced by field legumes and their time of incorporation (2nd cropping)

\begin{tabular}{|c|c|c|c|c|c|c|c|}
\hline Treatments & $\begin{array}{l}\text { Number } \\
\text { of pani- } \\
\text { cles per } \\
\mathrm{m}^{2}\end{array}$ & $\begin{array}{l}\text { Panicle } \\
\text { length } \\
\text { (cm) }\end{array}$ & $\begin{array}{l}\text { Number } \\
\text { of grains } \\
\text { per } \\
\text { panicle }\end{array}$ & $\begin{array}{l}\text { Weight } \\
\text { of grains } \\
\text { per } \\
\text { panicle } \\
\text { (g) }\end{array}$ & $\begin{array}{l}\text { Weight } \\
\text { of } 1000 \\
\text { grains } \\
\text { (g) }\end{array}$ & $\begin{array}{l}\text { Grain } \\
\text { yield } \\
\left(t \text { ha }^{-1}\right)\end{array}$ & $\begin{array}{l}\text { Harvest } \\
\text { index }\end{array}$ \\
\hline
\end{tabular}

Field legumes

$\begin{array}{llllllll}\text { Mungbean } & 187.22 & 23.77 & 110.10 & 2.39 & 21.73 & 1.96 & 0.42 \\ \text { Cowpea } & 188.00 & 23.65 & 106.12 & 2.32 & 21.78 & 1.90 & 0.39 \\ \text { Bushbean } & 190.68 & 24.09 & 112.72 & 2.48 & 22.06 & 2.07 & 0.43\end{array}$

Time of Incorporation

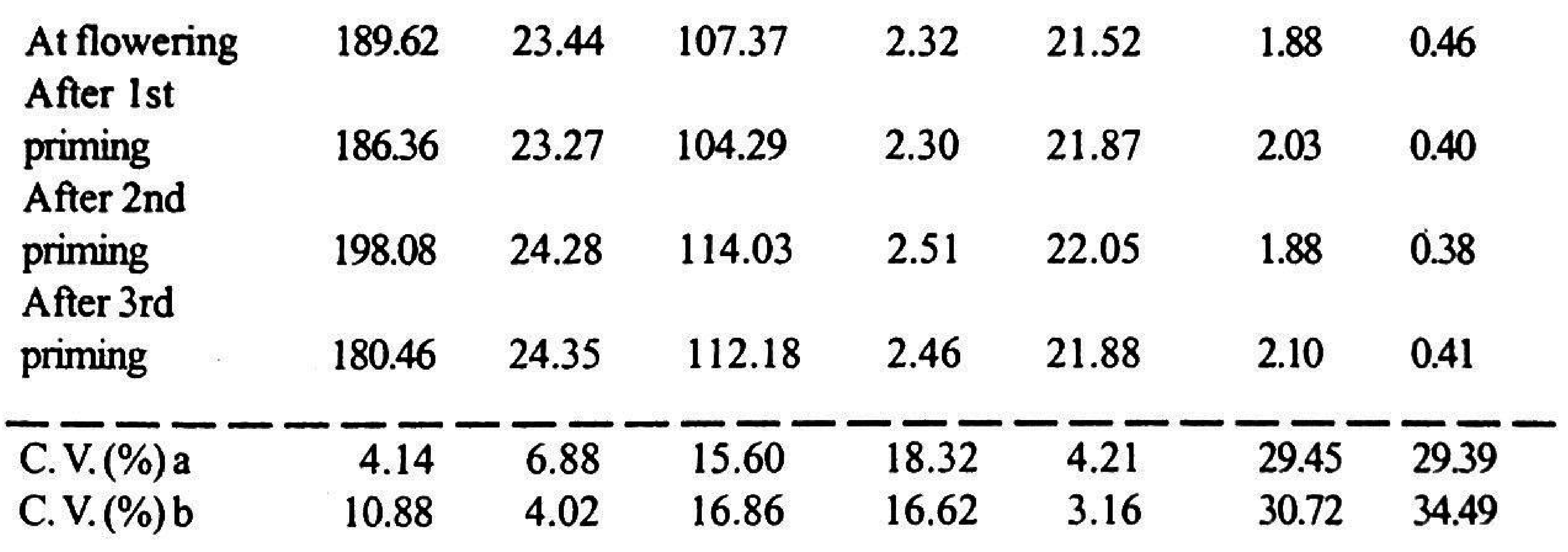

Treatment means within each column designated by a common letter and those without letter designations are not significantly different at 5\% level, DMRT and ANOVA, respectively

significantly affect the bulk density as well as the chemical properties of the soil planted to upland rice. Markedly lower bulk density values were obtained when mungbean and bushbean herbage were utilized. Interaction effects between species of field legumes and time of their incorporation as green manure were noted on soil $\mathrm{pH}$ and organic matter content.

Similarly, most of the agronomic and yield parameters of upland rice were not influenced by the treatments involved. Interaction effects between the species of field legumes and the time of their incorporation was noted on 
Table 10. Cost and return analysis of upland rice production as influenced by field legumes and their time of incorporation

\begin{tabular}{|c|c|c|c|c|c|c|}
\hline \multirow[t]{2}{*}{ Treatment } & \multicolumn{6}{|c|}{ Grain yield (t ha - 1 ) } \\
\hline & Legume & $\begin{array}{ll}\text { Rice } & \text { Rice } \\
\text { (1st } & \text { (2nd } \\
\text { crop) } & \text { crop) }\end{array}$ & $\begin{array}{l}\text { Gross } \\
\text { Income } \\
\text { (PhP) }\end{array}$ & $\begin{array}{l}\text { Gross } \\
\text { Expenses } \\
(\mathrm{PhP})\end{array}$ & $\begin{array}{l}\text { Net } \\
\text { Income } \\
(\mathrm{PhP})\end{array}$ & $\begin{array}{l}\text { Return } \\
\text { on } \\
\text { Invest- } \\
\text { ment (ROI) }\end{array}$ \\
\hline
\end{tabular}

Field legumes

$\begin{array}{llllllll}\text { Mungbean } & 0.44 & 2.07 & 1.98 & 47,012.00 & 20,983.02 & 26,028.98 & 1.24 \\ \text { Cowpea } & 0.44 & 2.07 & 1.98 & 71,650.00 & 22,9551.02 & 48,698.98 & 2.12 \\ \text { Bushbean } & 0.11 & 2.07 & 1.98 & 45,250.00 & 22,331.14 & 22,918.86 & 1.03\end{array}$

Time of Incorporation

$\begin{array}{lccccccc}\text { At flowering } & - & 2.08 & 1.97 & 36,450.00 & 21,589.86 & 14,860.14 & 0.69 \\ \begin{array}{l}\text { After 1st } \\ \text { priming }\end{array} & 0.33 & 2.08 & 1.97 & 56,770.00 & 22,138.96 & 34,631.04 & 1.56 \\ \begin{array}{l}\text { After 2nd } \\ \text { priming }\end{array} & 0.30 & 2.08 & 1.97 & 53,250.00 & 22,270.30 & 30,979.70 & 1.39 \\ \begin{array}{l}\text { After 3rd } \\ \text { priming }\end{array} & 0.35 & 2.08 & 1.97 & 53,543.38 & 22,352.30 & 31,191.08 & 1.40\end{array}$

Note: Gross income was computed based on the farm gate price of palay at $\mathrm{PhP} 9.00$ per $\mathrm{kg}$, mungbean at $\mathrm{PhP} 25$ per $\mathrm{kg}$, cowpea and bushbean at PhP80 per kg. Same yield level in rice per cropping was used as basis since treatment effects were statistically similar.

harvest index.

Cowpea was found to be the most profitable green manure crop upland rice. Regardless of field legumes used, herbage incorporation after from priming operation generated the highest net income. As expected, green manuring at flowering stage produced the lowest net income. This implies that the usual practice of turning under green manure crops at flowering stage can be modified to later stages of their growth, that is, when priming operation has been done. This means that farmers will not only gain additional return from the harvested produce but save part of their production inputs aside from enriching soil nutrients and improving its physical properties. 


\section{REFERENCES}

BRADY, N. C. 1984. The Nature and Properties of Soils. (9th ed.) Macmillan Publ. Co. Inc. $750 \mathrm{pp}$.

CAPUNO, R. B., FABRE, B. E. and ESCALADA, R. G. 1980. Growth and yield of sorghum as influenced by green manure and soil organic matter content. Annals of Tropical Research 2(2):105-110.

JAVIER, R. R. 2002. Cultural management manipulation for baby corn (Zea mays Linn.) production. I. Effects of variety and organic manure on the growth and yield of baby com. Annals of Tropical Research 24(1):35-48.

OGBONNA, C. K. C. and MABBAYAD, B. B. 1984. The influence of stylo-com intercropped and the incorporation of stylo herbage as green manure on the yield of com (Zea mays L.) and on soil properties. Phil Journ. of Crop Science 9(1):2528.

PCARR. 1978. The Philippines Recommends for Soil Fertility Management. pp. 108.

SUllivaN, P. 2003. An Overview of Cover Crops and Green Manures. $<$ http:www.attra.ncat.org >

SULLIVAN, P. 2003. Organic Rice Production.<http:www.attra.ncat.org>

THOMPSON, L. M. and TROEH, F. R. 1973. Soils and Soil Fertility. (3rd ed.)<McGraw Hill Book Co. New York. 498 pp. 